\title{
The effect of a novel antagonist of growth hormone releasing hormone on cell proliferation and on the key cell signaling pathways in nine different breast cancer cell lines
}

\author{
EVA POZSGAI $^{1,2,3}$, ANDREW V. SCHALLY $^{1,2}$, ENIKO HOCSAK $^{3}$, MARTA ZARANDI $^{1,2}$, \\ FERENC RICK $^{1,2,4}$ and SZABOLCS BELLYEI ${ }^{1,2,5}$
}

\begin{abstract}
${ }^{1}$ Veterans Affairs Medical Center and South Florida Veterans Affairs Foundation for Research and Education; ${ }^{2}$ Department of Pathology, University of Miami, Miller School of Medicine, Miami, FL 33125, USA; Departments of ${ }^{3}$ Biochemistry and Medical Chemistry, ${ }^{4}$ Anatomy, and ${ }^{5}$ Oncology, University of Pécs, Pécs 7624, Hungary
\end{abstract}

Received April 4, 2011; Accepted May 23, 2011

DOI: 10.3892/ijo.2011.1098

\begin{abstract}
Growth hormone releasing hormone (GHRH) antagonists have been developed for the treatment of various cancers. We investigated the effects of a novel GHRH antagonist, MIA-602, on nine breast cancer cell lines, differing in their expression for estrogen-, progesterone- and HER-2 receptors. We detected the presence of pituitary-type GHRH receptors (pGHRH-R) on 6 of the 9 breast cancer cell lines. The main splice variant of pGHRH-R, SV1, was found on all 9 cell lines. MTT assay showed that following treatment with MIA-602, cell viability decreased significantly in all 9 cell lines. The reduction in cell viability was greater in cells positive for both pGHRH-R and SV1, than in cells positive for only SV1, but the difference was not significant. Using Western blotting, we demonstrated that the levels of phosphoAkt, -GSK3 $\beta$ and -ERK1/2 decreased significantly following exposure to MIA-602 and the level of phospho-p38 increased after treatment. The reduction of the phosphorylated antiapoptotic proteins was significantly greater in cells where both pGHRH-R and SV1 were present, than where only SV1 was expressed. In conclusion, our study shows that MIA-602 is effective against a wide range of breast cancer cells in vitro, independently of their receptor positivity, suggesting the potential use of GHRH antagonists also in the treatment of triple-negative breast cancer. The effect of MIA-602 was mediated nearly as well in tumors that expressed only the SV1 receptor compared to those in which both SV1 and pGHRH-R
\end{abstract}

\footnotetext{
Correspondence to: Dr Szabolcs Bellyei, Veterans Affairs Medical Center and South Florida Veterans Affairs Foundation for Research and Education, 1201 Northwest 16th street, Research (151), Miami, FL 33125, USA

E-mail: bellyeisz@gmail.com
}

Key words: breast cancer, growth hormone releasing hormone receptor, SV1, growth hormone releasing hormone antagonist, Akt, ERK were present, although a difference could be detected at the level of cell signaling.

\section{Introduction}

Breast cancer is the most common malignancy in women and represents a leading cause of cancer-related deaths among the female patients worldwide (1-3). The great diversity of breast cancers in their histological and behavioral characteristics requires the application of tailored therapies. Effective targeted treatment for breast cancer positive for estrogen-, progesteroneand HER-2 receptors is currently available but satisfactory treatment modalities for triple-negative breast cancers still need to be developed $(4,5)$.

Antagonistic analogues of growth hormone releasinghormone (GHRH), developed in our laboratory, have been shown to inhibit the growth of various cancers (6-11), through indirect and direct pathways (6). Thus, GHRH antagonists can suppress tumor growth indirectly by blocking $\mathrm{GH}$ release from the pituitary and consequently the hepatic production of IGF-I $(6,12)$, which is an established mitogen for various cancers (13), is likewise inhibited. Nevertheless, GHRH antagonists, exert their main antitumor effects through direct mechanisms $(12,14)$, by the inhibition of tumoral GHRH and IGF-I and/or IGF-II (6,14-16), which serve as autocrine/paracrine growth factors. Pituitary-type GHRH receptors (pGHRH-R) and their splice variants (SVs) have been detected in different human cancers and various cancer cell lines (17-21).

Earlier reports have shown that GHRH antagonists decrease cell viability of breast cancers in vitro (9-11) and inhibit the growth and metastases of orthotopic breast cancer models in vivo $(8,16)$. Previously, we demonstrated that GHRH antagonists induce cell death through the major apoptotic pathways and by a membrane destabilizing effect on the mitochondrial membrane potential in two glioblastoma cell lines (22). In the present study, our goal was to screen a number of breast cancer cell lines, differing in their expression of estrogen/progesterone and HER-2 receptors, for their response to treatment with a GHRH antagonist. This is the first report comparing the effects of a novel, potent GHRH antagonist, MIA-602, on 
proliferation of breast cancer cells as well as on the key cell signaling pathways.

\section{Materials and methods}

Peptides and chemicals. GHRH antagonist, MIA-602, was synthesized in our laboratory by solid-phase methods and purified by reversed-phase HPLC as described previously (18). The chemical structure of MIA-602 is [(PhAc-Ada $)^{0}-\mathrm{Tyr}^{1}$, D-Arg ${ }^{2}, \mathrm{Fpa}^{56}, \mathrm{Ala}^{8}, \mathrm{Har}^{9}, \mathrm{Tyr}(\mathrm{Me})^{10}, \mathrm{His}^{11}, \mathrm{Orn}^{12}, \mathrm{Abu}^{15}, \mathrm{His}^{20}$, $\mathrm{Orn}^{21}, \mathrm{Nle}^{27}$, D-Arg ${ }^{28}, \mathrm{Har}^{29}$ ]hGH-RH(1-29)NH ${ }_{2}$. GHRH(1-29) $\mathrm{NH}_{2}$ was also synthesized in our laboratory. For the experiments, GHRH(1-29) $\mathrm{NH}_{2}$ and MIA-602 were dissolved in $0.1 \%$ DMSO and diluted with incubation media.

Cell lines. The cell lines (HCC1806, MDAMB468, MDAMB435S, MCF7, T47D, HCC1937, BT474, MX-1) were obtained from American Type Culture Collection (Manassas, VA, USA) and cultured at $37^{\circ} \mathrm{C}$ in a humidified $95 \%$ air $/ 5 \%$ $\mathrm{CO}_{2}$ atmosphere. The culture media were purchased from Gibco (Carlsbad, CA).

Polymerase chain reaction $(P C R)$. Total RNA was extracted using the Nucleospin kit (Macherey-Nagel, Germany). The yield and quality of total RNA was determined spectrophotometrically using the absorbance at 260 and 260/280 $\mathrm{nm}$ ratio, respectively. RNA ( $2 \mu \mathrm{g}$ ) with a final volume of $40 \mu \mathrm{l}$ was reverse transcribed into cDNA with the QuantiTect ${ }^{\circledR}$ reverse transcription kit (Qiagen, Valencia, CA) using Veriti ${ }^{\text {TM }}$ 96-well thermal cycler (Applied Biosystems, Foster City, CA). We evaluated the expression of mRNA for human pGHRH-R, splice variant 1 of GHRH-R (SV1) and $\beta$-actin. Probes and primers for pGHRH-R, and $\beta$-actin and sense- and antisense-specific primers for SV1 were described previously (23). All real-time PCR reactions were performed in the $\mathrm{iCycler}_{\mathrm{iQ}}^{\mathrm{TM}}$ real-time PCR detection system (Bio-Rad, Hercules, CA). All thermal cycling conditions were described in former studies (23). All samples were run as described earlier (24). Briefly, samples were run in triplicate and each well of PCR reaction contained $25 \mu \mathrm{l}$ as final volume including $2 \mu \mathrm{l}$ of cDNA, $200 \mathrm{nM}$ of gene specific primers and $400 \mathrm{nM}$ of probes. $\mathrm{iQ}^{\mathrm{TM}}$ Supermix (Bio$\mathrm{Rad}$ ) was used in the PCR reactions for $\mathrm{PGHRH}-\mathrm{R}$, and $\beta$-actin and $\mathrm{iQ}^{\mathrm{TM}}$ SYBR-Green Supermix (Bio-Rad) for SV1. The efficiencies of all primers (Invitrogen Life Technologies, Carlsbad, CA) and probes (Integrated DNA Technologies, Coralville, IA) were tested prior to the experiments and found to be efficient in the range of $95-105 \%$. Normal human pituitary was used as positive control and human $\beta$-actin as a housekeeping gene. Negative samples were run in each reaction consisting of no-RNA in reverse transcriptase reaction and no-cDNA in $\mathrm{PCR}$ reaction.

Proliferation assay. Cells were seeded onto 96-well-plates at a starting density of 2500 cells/well, cultured overnight, starved for $24 \mathrm{~h}$ with medium containing no FBS and then treated with GHRH(1-29) $\mathrm{NH}_{2}$ or GHRH antagonist, MIA-602 for $48 \mathrm{~h}$. After the treatment, the relative number of viable cells was measured in comparison with the untreated control and the solvent control, using Cell Titer 96 AQueusus Assay (Promega) at $490 \mathrm{~nm}$ in a Victor3 multilabel counter (Perkin-
Table I. GHRH, SV-1 and ER receptor status of the nine breast cancer cell lines.

\begin{tabular}{lccc}
\hline $\begin{array}{l}\text { Breast cancer } \\
\text { cell lines }\end{array}$ & $\begin{array}{c}\text { GHRH } \\
\text { receptor }\end{array}$ & $\begin{array}{c}\text { SV-1 } \\
\text { receptor }\end{array}$ & $\begin{array}{c}\text { ER } \\
\text { receptor }\end{array}$ \\
\hline HCC1806 & + & + & + \\
MDAMB468 & + & + & - \\
HCC1937 & + & + & - \\
MCF7 & + & + & + \\
BT474 & + & + & + \\
MX1 & + & + & - \\
T47D & - & + & + \\
MDMB435S & - & + & - \\
MDAMB231 & - & + & - \\
\hline
\end{tabular}

Elmer, Waltham, MD, USA) according to the manufacturer's instructions. All experiments were done at least in quadruplate and repeated three times. The percentage of cell survival was determined by comparing the absorbance value of the vehicle control.

Isolation of subcellular fractions. Cells were harvested and centrifuged at low-speed, then the pellet was dispersed by vortexing in lysis buffer [50 mM Tris- $\mathrm{HCl}(\mathrm{pH} 8.0), 1 \%$ Triton X-100, 10\% glycerol, $1 \mathrm{mM}$ EDTA, $250 \mathrm{mM} \mathrm{NaCl}$, $1 \mathrm{mM}$ dithiothreitol, $1 \mathrm{mM}$ phenylmethylsulfonylfluoride, $2 \mathrm{mM}$ sodium vanadate, $100 \mathrm{mM}$ sodium fluoride, $10 \mathrm{mg} / \mathrm{ml}$ aprotinin, $10 \mathrm{mg} / \mathrm{ml}$ leupeptin and $10 \mathrm{mg} / \mathrm{ml}$ pepstatin] for $10 \mathrm{~min}$ at $4^{\circ} \mathrm{C}$. Isolation of cytosol, nuclear and mitochondrial fractions was carried out by standard protocols as described previously (25).

Western blot. Cells were washed with PBS, and directly lysed in lysis buffer. Cell lysates were adjusted to equal protein concentrations (NanoDrop Technologies, Inc., Wilmington, $\mathrm{DE}$ ), resuspended in $2 \mathrm{X}$ sample loading buffer containing 4\% SDS, 20\% glycerol, $120 \mathrm{mM}$ Tris and bromophenol blue, and boiled for $5 \mathrm{~min}$. Protein samples were then subjected to SDS-polyacrylamide gel electrophoresis. Proteins on the gel were transferred onto nitrocellulose membranes that were blocked with 50-50\% Odyssey buffer and phosphate-buffered saline (PBS) for $1 \mathrm{~h}$ at room temperature. Subsequently, the membranes were incubated with the indicated primary antibodies overnight at $4^{\circ} \mathrm{C}$. p-AKT, p-ERK1/2, pGSK3 $\beta$ and phosphop38 primary antibodies were purchased from Cell Signaling. $\alpha$-tubulin primary antibody was obtained from Calbiochem. After washing with PBS containing 0.1\% Tween-20, the membranes were incubated with the appropriate secondary antibody. The immunoreactive bands were visualized with the Odyssey Infrared Imaging System and V. 3.0 software was used (LI-COR Biosciences, Lincoln, Nebraska).

Statistical analysis. Results are expressed as means \pm SE. Results were compared using Student's t-test, $\mathrm{p}<0.05$ being accepted as statistically significant. 
A

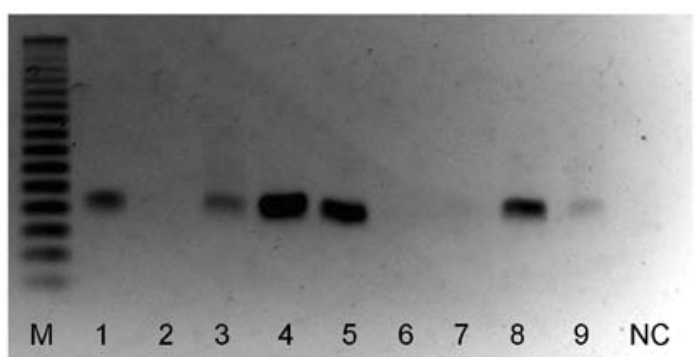

B

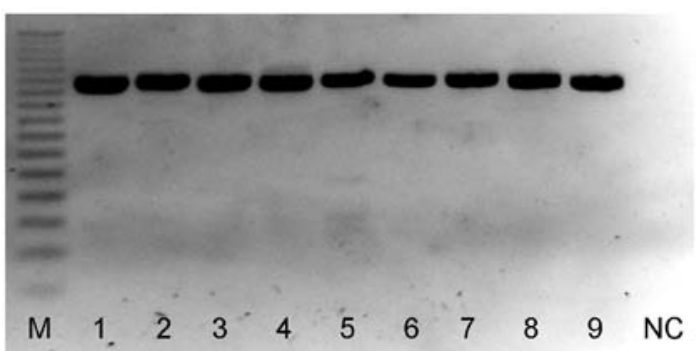

Figure 1. Reverse-transcription PCR gel electrophoresis of receptors of GHRH (A) and SV1 (B) from 9 different breast cancer cell lines. M, 50-bp DNA size marker; 1, MDAMB468; 2, MDAMB435S; 3, BT447; 4, MX1; 5, HCC1806; 6, T47D; 7, MDAMB231; 8, HCC1937; 9, MCF7; NC, negative control.

\section{Results}

The presence of $p G H R H-R$ and SVI on nine different breast cancer cell lines. Reverse transcribed mRNA from nine different breast cancer cell lines (HCC1806, MDAMB468, MDAMB435S, MCF7, T47D, HCC1937, BT474, MX-1) was subjected to PCR to determine the expression of the pituitary type of GHRH receptor (Fig. 1A) and its main truncated splice variant, SV1 (Fig. 1B). The 523 bp amplicon for SV1 beginning within the intron between exon 3 and 4 of the GHRH-R gene and ending in the exon 7 was identified in all the nine cell lines. Specific primers for the pGHRH-R spanning from exon 3 to exon 8 were used and the amplification of a $145 \mathrm{bp}$ fragment was detected in 6 (HCC1806, MDAMB468, MCF7, HCC1937, BT474, MX-1) of the nine cell lines (Fig. 1A and B, and Table I). Our results are in line with previous reports on the presence of pGHRH-R and SV1 on breast cancer cell lines $(11,26)$.

The inhibitory effect of GHRH antagonist MIA-602 on the cell viability of breast cancer cell lines. Nine breast cancer cell lines were treated with GHRH antagonist MIA-602 at $0.1,1,5$ and $10 \mu \mathrm{M}$ concentrations for $48 \mathrm{~h}$. The untreated cells served as negative controls. The exposure to MIA-602 at all concentrations resulted in a reduced cell proliferation.
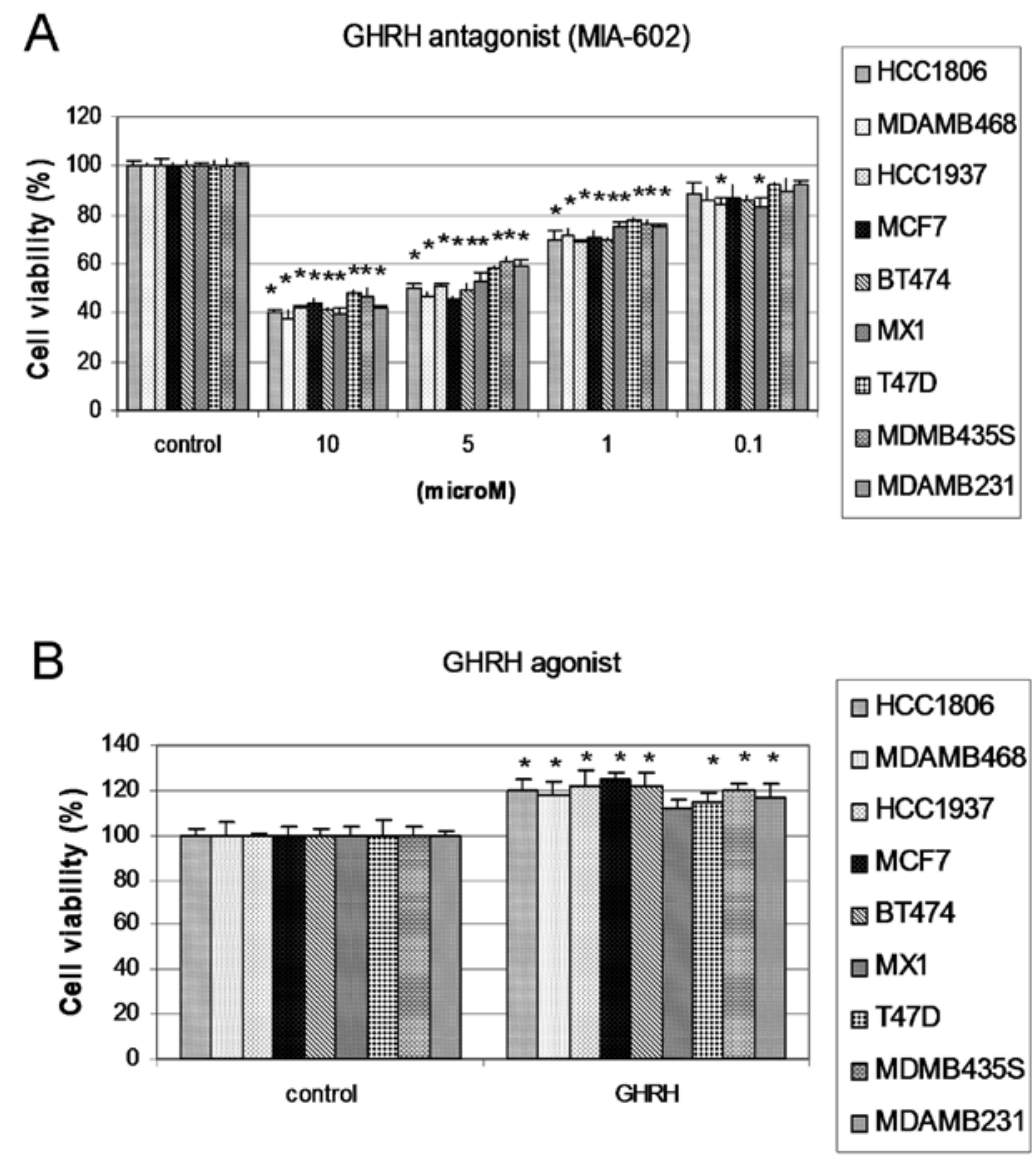

Figure 2. Inhibitory effect of GHRH antagonist, MIA-602 (A), at different concentrations, on 9 different breast cancer cell lines. The effect of GHRH(1-29)NH (B) at $1 \mu \mathrm{M}$ concentration on the different breast cancer cell lines cell lines. Cell viabilities were measured by an MTT (methylthiazolydiphenyl-tetrazolium bromide) assay and were expressed as percentage of untreated cells. The results are the mean \pm SEM of three independent experiments performed at least in quadruplicate. ${ }^{*} \mathrm{p}<0.05$. 
We determined that the concentration at which cellular growth was inhibited by $30 \%\left(\mathrm{IC}_{30}\right)$ was $1 \mu \mathrm{M}$ and hereafter used this concentration in subsequent experiments. After treatment with $1 \mu \mathrm{M}$ MIA-602, the cell viability decreased significantly in all cancer cell lines with a slightly greater reduction in the 6 GHRH-R-positive cell lines (Fig. 2A, Table I). Treatment with GHRH(1-29) $\mathrm{NH}_{2}$, on the other hand, augmented the proliferation of the cell lines (Fig. 2B). Used at the same concentration, MIA-602 inhibited cell proliferation and abolished the effect of exogenous GHRH(1-29) $\mathrm{NH}_{2}$ (data not shown).

The effect of MIA-602 on key cell signaling pathways in breast cancer cell lines. Previously, we reported that the exposure of glioblastoma cells to MIA-602 changed the levels of the anti-apoptotic proteins, phospho-Akt, phospho-GSK3 $\beta$ and phospho-ERK1/2 (38). In this study we treated nine breast cancer cell lines, differing in their receptor positivity, with $1 \mu \mathrm{M}$ MIA-602, and using Western blotting determined the levels of the anti-apoptotic proteins at $0,5,10$ and $30 \mathrm{~min}$ following exposure. In accord with earlier findings, treatment with MIA-602 caused a significant decrease in the expression of p-Akt and pGSK $3 \beta$ at $5 \mathrm{~min}$, a greater reduction at $10 \mathrm{~min}$, then an increase to their original, $0 \mathrm{~min}$, level at $30 \mathrm{~min}$ (Fig. 3A and B). This pattern of reduction and elevation was also apparent in the p-ERK1/2 levels (Fig. 3C). It is interesting to note, that the degree of change in the levels of antiapoptotic proteins correlated with the GHRH-R positivity of the cell lines: the cell lines with both GHRH and SV1 receptors displayed a more striking reduction in the levels of the anti-apoptotic proteins, than those with only SV1 positivity (Fig. 3A, B and C). When the cells were treated with GHRH(1-29) $\mathrm{NH}_{2}$ the levels of p-Akt, p-GSK3 $\beta$ and pERK1/2 rose continuously at 5 and $10 \mathrm{~min}$ then gradually fell to their initial levels at $30 \mathrm{~min}$ (Fig. 3A, B and C). The amount of phopho-p38 expression was examined at 0 time point and $24 \mathrm{~h}$ following treatment. The former time point served as a control. Exposure to MIA-602 produced a clear activation of p38 MAP kinase phosphorylation (Fig. 3D). In contrast, the level of p38 activation in GHRH(1-29) $\mathrm{NH}_{2}$-treated cells was only slight (data not shown). We did not detect a difference between the intensities of phosphorylation of p38 in the nine breast cancer cell lines after MIA-602 treatment.

\section{Discussion}

GHRH is known to be expressed in various tumors, including prostatic, ovarian, endometrial and breast cancers (27-32). Extra hypothalamic production of GHRH has been linked to increased mitogenic activity in lymphocytes and testicular germ cells (33). Furthermore, a recent study demonstrated that GHRH stimulates the proliferation of MDA-MB-231 breast cancer cells in a doseand receptor-dependent manner, through the Ras/Raf/MAPK pathway (34). During the past decade, the efficacy of GHRH antagonists on tumor growth inhibition has been reported in multiple publications (6). The evidence indicates that GHRH antagonists act primarily by blocking the binding of autocrine GHRH to cancer cells $(8,35)$. The receptors which mediate the effects of GHRH and GHRH antagonists have been identified and four truncated splice variants (SVs) of the pGHRH-R have been found (26). In our study, in accordance with earlier investigations $(9,26)$ we could detect the presence of SV1 in all breast cancer cell lines examined, while pGHRH-R was present in only 6 cell lines. The occurrence of either type of GHRH receptors was not related to the presence of estrogen/ progesterone or HER-2 receptors. SV1 of GHRH-R is thought to be the main SV that transmits the effects of GHRH and its antagonists in cancers (26). Accordingly, the MTT assay showed that GHRH antagonist, MIA-602, was effective in significantly decreasing cell viability in all nine cell lines. The proliferation of the two cell lines, MDAMB435 and T47D, expressing only SV1 receptors, was inhibited to a lesser degree than that in cells positive for both the pGHRH-R plus SV-1 cells, however the difference was not significant. These results support the previous findings that GHRH antagonists can exert their antiproliferative effects on tumors and cell lines, even when the pGHRH-R cannot be detected and only the SV-type receptors are present $(11,36)$.

The role of GHRH in the promotion of proliferation and prevention of apoptosis in cancer cells is well known $(34,37)$. Earlier reports have shown that GHRH stimulates ERK and Elk-1 activation (38), as well as the activation of the transcription factors CREB and CHOP $(39,40)$. Recently, we studied the signal transduction in glioblastoma cell lines following treatment with a GHRH antagonist and found that it affects cell death through the key pro-apoptotic pathways: the reduction of phosphorylated Akt, GSK3 $\beta$ and p44/42 MAPK, the cleavage of PARP and caspase-3 as well as through the intracellular translocation of proteins AIF, EndoG and cyt c (22). Our group also demonstrated that antagonism of GHRH abolishes the integrity of the mitochondrial membrane, thus promoting apoptosis $(22,41)$. In the present study we investigated the level of phosphorylation of Akt, GSK3 $\beta$ and p44/42 MAPK following exposure to a novel GHRH antagonist, MIA-602, in nine different breast cancer cell lines. As expected, there was a reduction in the levels of phosphorylation of all three anti-apoptotic proteins in all the cell lines following treatment with MIA-602 and an increase in the intensities of phospo-p38 compared to GHRH(1-29) $\mathrm{NH}_{2}$-treated cells. Nevertheless, it was not previously shown, that the levels of phosphorylated Akt, GSK $3 \beta$ and ERK1/2 would be significantly lower at 5 and 10 min in SV1 plus pGHRH-R-positive cells than in cells expressing only SV-1. Similarly, differences in the reduction of cell viability of such cells have not been observed in the MTT assay. This finding may be explained by the assumption that, signal transduction is more rapid where the signal is mediated through both types of receptors and thus results in a diminished phosphorylation in a shorter time. The difference, nevertheless, becomes smaller by $48 \mathrm{~h}$, by the time the MTT assay is completed. It is clear from our study, that the antiapoptotic effect of GHRH antagonists is transmitted through the main truncated splice variant of the GHRH-R, SV1, almost as well as when both types of receptors are present on the cells. Whether the presence of both pGHRH-R and SV1 provides a long-term disadvantage for breast cancer cells compared to cells expressing only SV1 is not established and further studies are required. Altogether, our results indicate that, it might be useful to test breast cancer specimens not only for the presence of estrogen/progesterone and HER-2 receptors, but also for pGHRH-R and SV1 positivity in the future, if a therapy with GHRH antagonists is contemplated. 
A

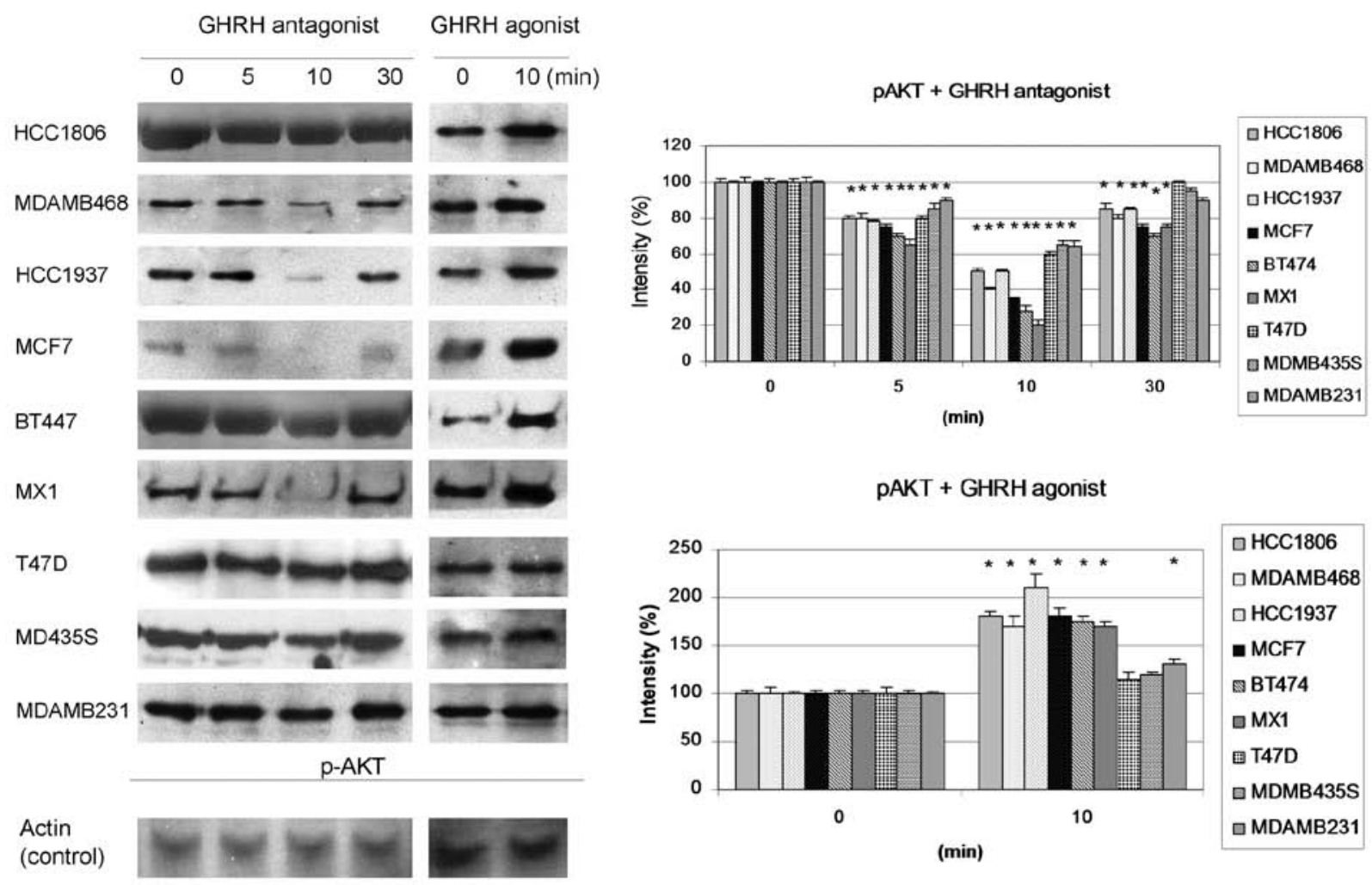

B

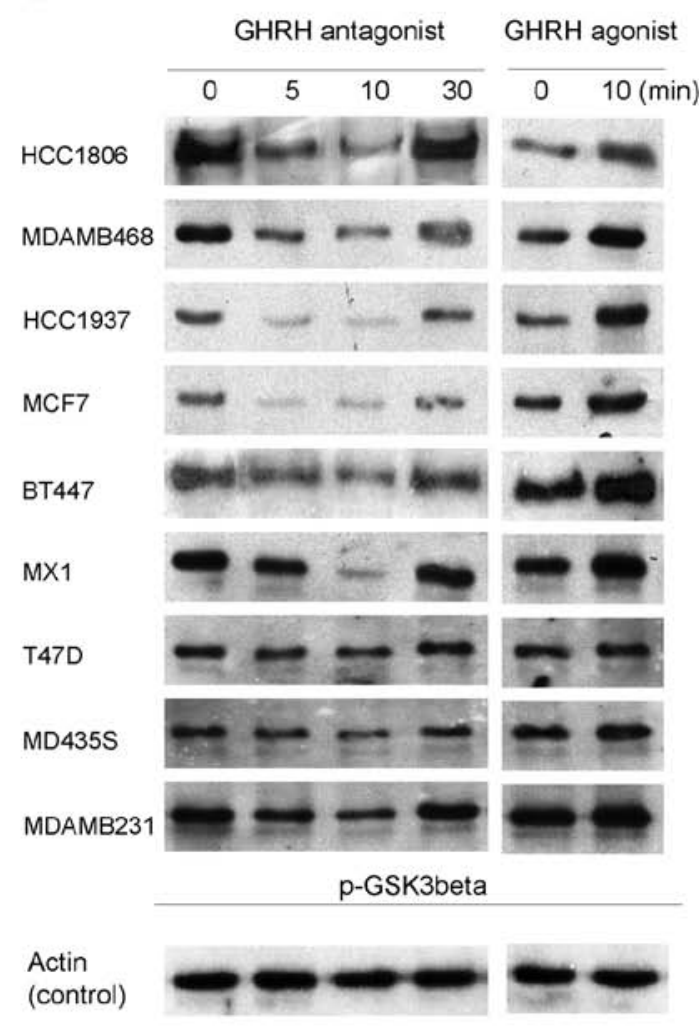

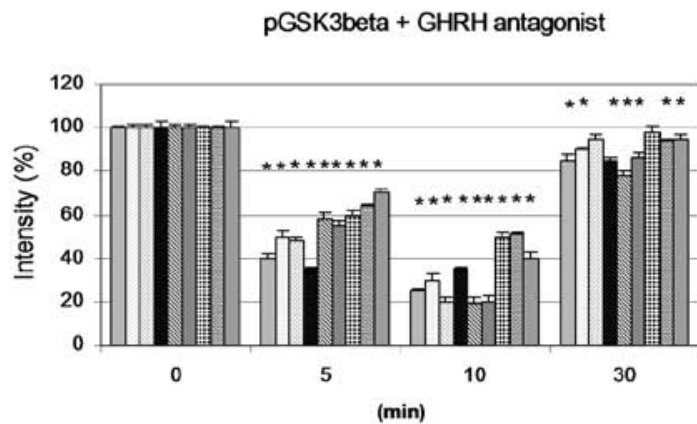

pGSK3beta + GHRH agonist

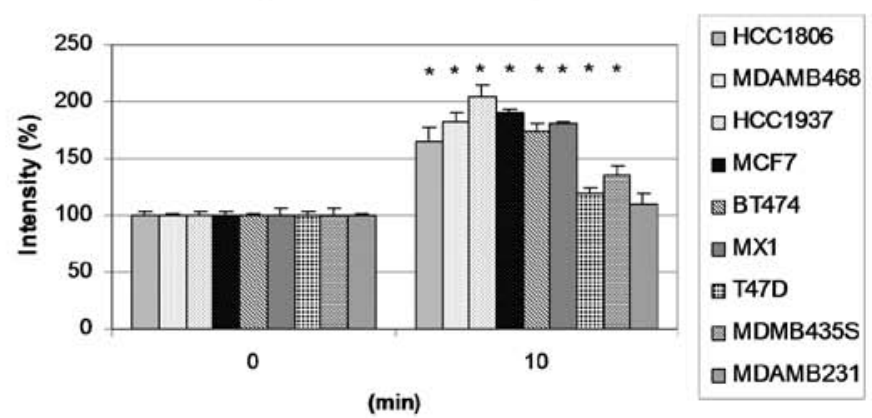

Figure 3 (A and B). The effect of GHRH antagonist, MIA-602 and GHRH(1-29) $\mathrm{NH}_{2}$ on the activation of (A) Akt (B) GSK3 3.

In conclusion, this is the first report on screening nine different breast cancer cell lines and comparing their responses to GHRH antagonist treatment. The responses to GHRH antagonist treatment have not been investigated previously in 
C

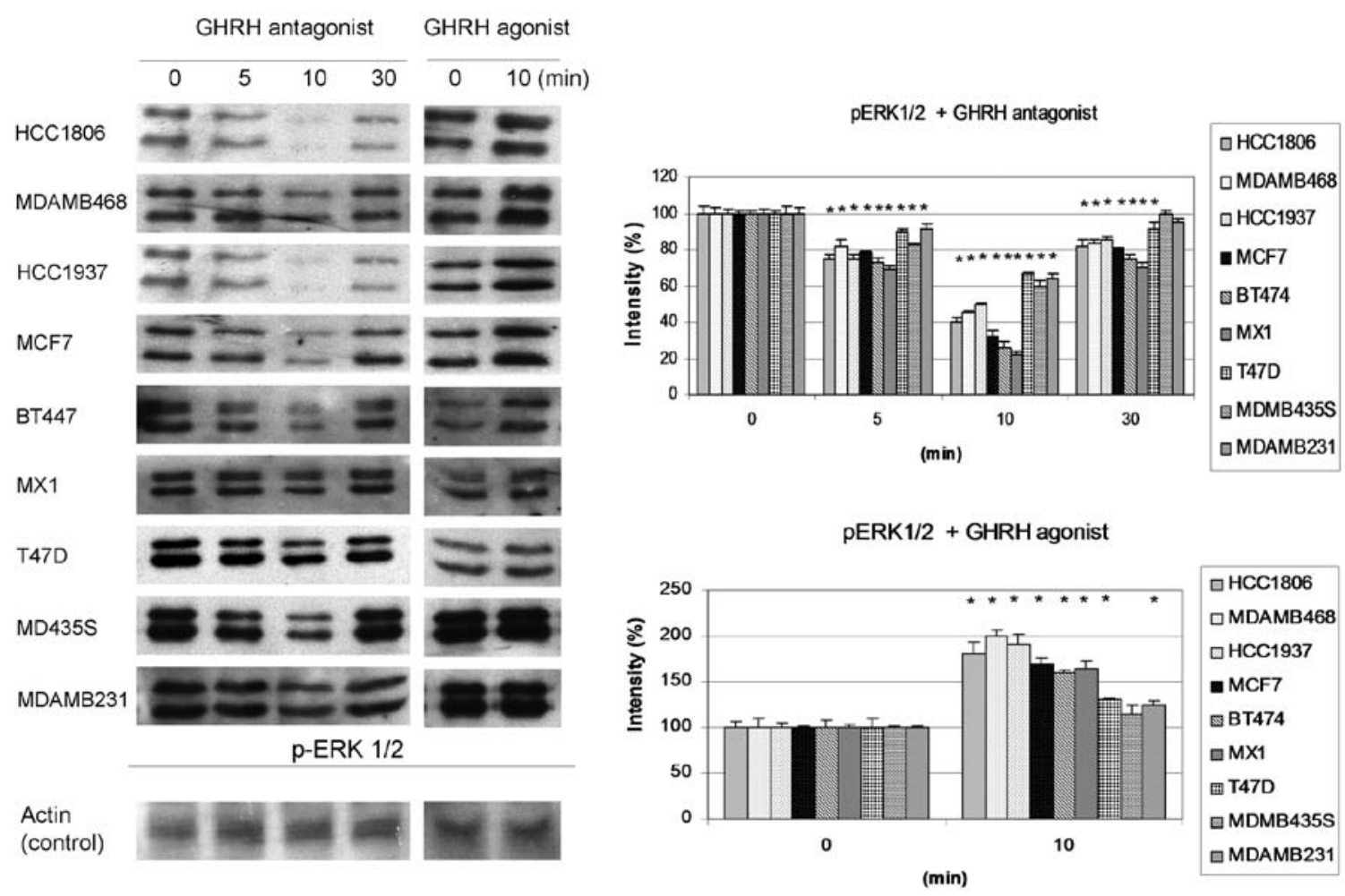

D

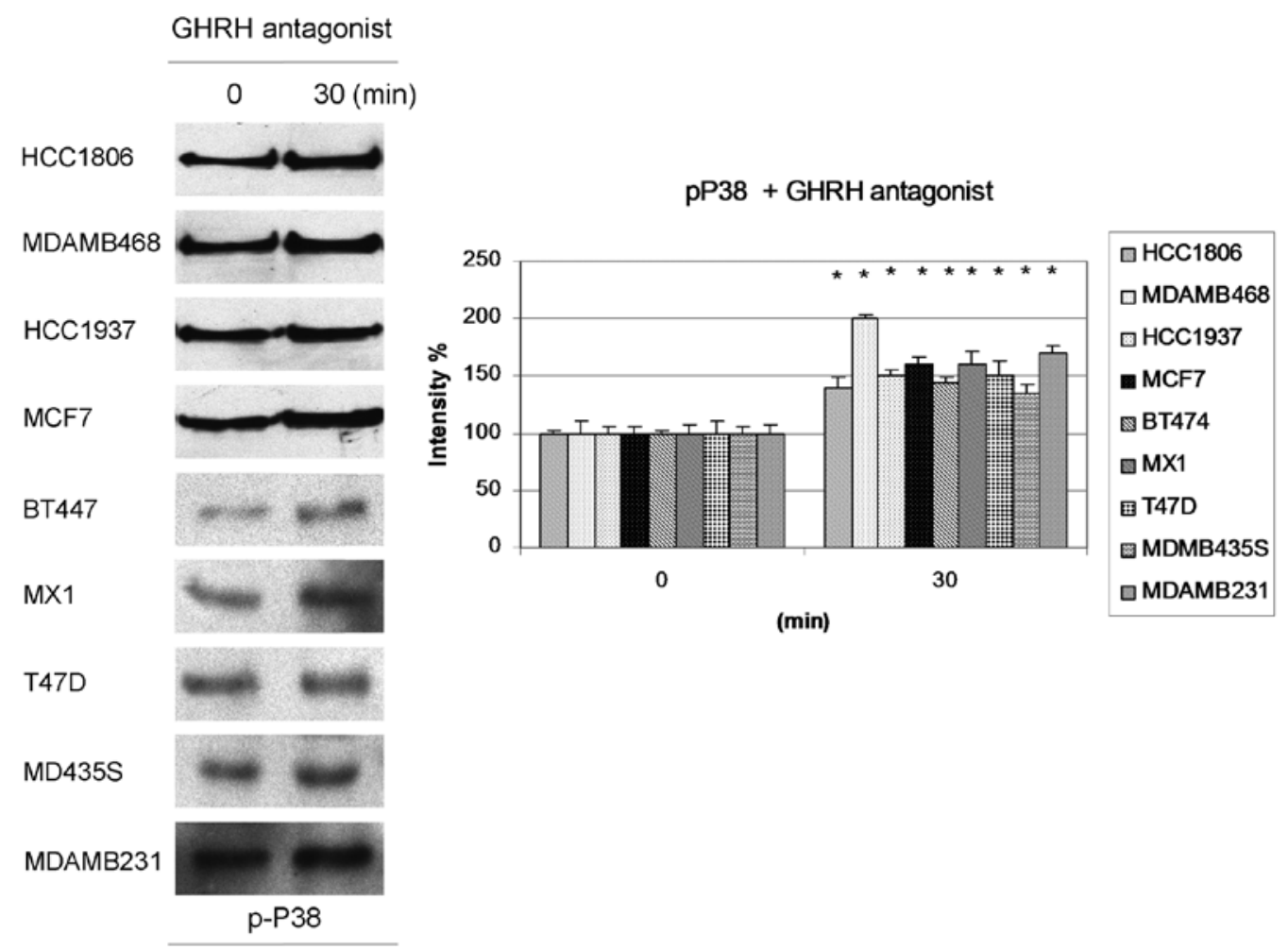

Actin

(control)

Figure 3 (C and D). The effect of GHRH antagonist, MIA-602 and GHRH(1-29) $\mathrm{NH}_{2}$ on the activation of (C) ERK and (D) p38 kinases in samples from nine different breast cancer cell lines. The detection of pAkt, pGSK $3 \beta$ and pERK was carried out at 0,5,10 and 30 min and detection of phospho-p38 at 0,30 min, and all were demonstrated by immuno-blotting utilizing phosphorylation specific primary antibodies against the given kinase. $\alpha$-tubulin immunoreactivity was used to show even loading. Representative blots of three independent experiments are presented. The results are mean \pm SEM of three independent experiments performed at least in quadruplicate. ${ }^{*} \mathrm{p}<0.05$. 
such a variety of breast cancer cell lines. We found, that the effect of MIA-602 is mediated almost as well in cells expressing only the SV1 receptor as in cell lines in which both SV1 and pGHRH-R are present, although a difference can be observed at the level of cell signaling. The current study clearly shows, that the new GHRH antagonist, MIA-602, is very efficacious against a wide spectrum of breast cancer cells, independently of their status for estrogen/progesterone and HER-2 receptors. Thus, the use of GHRH antagonists such as MIA-602, after further experimental studies and therapeutic trials, could provide an approach to the treatment of triple negative breast cancer, where endocrine therapy or other targeted therapies are not an option.

\section{Acknowledgements}

The work described in this paper was supported by the Medical Research Service of the Veterans Affairs Department, University of Miami Miller School of Medicine Departments of Pathology and Medicine, Division of Hematology/Oncology and South Florida Veterans Affairs Foundation for Research and Education (all to A.V.S.). E.P. and Sz.B. were on leave from the Department of Biochemistry and Clinical Chemistry and from the Department of Oncology, University of Pécs, Hungary. This work was also supported by grant from the Hungarian Science Foundation 68469, and by the Janos Bolyai Research Scholarship of the Hungarian Academy of Sciences.

\section{References}

1. Pollan M: Epidemiology of breast cancer in young women. Breast Cancer Res Treat 123 (Suppl 1): S3-S6, 2010.

2. Jemal A, Ward E and Thun MJ: Contemporary lung cancer trends among U.S. women. Cancer Epidemiol Biomarkers Prev 14: 582-585, 2005.

3. Coleman MP, Forman D, Bryant $\mathrm{H}$, et al: Cancer survival in Australia, Canada, Denmark, Norway, Sweden, and the UK, 1995-2007 (the International Cancer Benchmarking Partnership): an analysis of population-based cancer registry data. Lancet 377 : $127-138,2011$

4. Landis SH, Murray T, Bolden S and Wingo PA: Cancer statistics, 1998. CA Cancer J Clin 48: 6-29, 1998.

5. Dees EC and Kennedy MJ: Recent advances in systemic therapy for breast cancer. Curr Opin Oncol 10: 517-522, 1998.

6. Schally AV, Varga JL and Engel JB: Antagonists of growthhormone-releasing hormone: an emerging new therapy for cancer. Nat Clin Pract Endocrinol Metab 4: 33-43, 2008.

7. Schally AV and Varga JL: Antagonistic analogs of growth hormone-releasing hormone: new potential antitumor agents. Trends Endocrinol Metab 10: 383-391, 1999.

8. Chatzistamou I, Schally AV, Varga JL, et al: Inhibition of growth and metastases of MDA-MB-435 human estrogen-independent breast cancers by an antagonist of growth hormone-releasing hormone. Anticancer Drugs 12: 761-768, 2001.

9. Buchholz S, Schally AV, Engel JB, et al: Potentiation of mammary cancer inhibition by combination of antagonists of growth hormone-releasing hormone with docetaxel. Proc Natl Acad Sci USA 104: 1943-1946, 2007.

10. Seitz S, Hohla F, Schally AV, et al: Inhibition of estrogen receptor positive and negative breast cancer cell lines with a growth hormone-releasing hormone antagonist. Oncol Rep 20: 1289-1294, 2008.

11. Koster F, Engel JB, Schally AV, et al: Triple-negative breast cancers express receptors for growth hormone-releasing hormone (GHRH) and respond to GHRH antagonists with growth inhibition. Breast Cancer Res Treat 116: 273-279, 2009.

12. Schally AV, Comaru-Schally AM, Nagy A, et al: Hypothalamic hormones and cancer. Front Neuroendocrinol 22: 248-291, 2001

13. Khandwala HM, McCutcheon IE, Flyvbjerg A and Friend KE: The effects of insulin-like growth factors on tumorigenesis and neoplastic growth. Endocr Rev 21: 215-244, 2000.
14. Varga JL, Schally AV, Horvath JE, et al: Increased activity of antagonists of growth hormone-releasing hormone substituted at positions 8, 9 and 10. Proc Natl Acad Sci USA 101: 1708-1713, 2004

15. Szepeshazi K, Schally AV, Groot K, Armatis P, Hebert F and Halmos G: Antagonists of growth hormone-releasing hormone $(\mathrm{GH}-\mathrm{RH})$ inhibit in vivo proliferation of experimental pancreatic cancers and decrease IGF-II levels in tumours. Eur J Cancer 36: 128-136, 2000.

16. Kahan Z, Varga JL, Schally AV, et al: Antagonists of growth hormone-releasing hormone arrest the growth of MDA-MB-468 estrogen-independent human breast cancers in nude mice. Breast Cancer Res Treat 60: 71-79, 2000.

17. Chatzistamou I, Schally AV, Varga JL, Groot K, Armatis P and Bajo AM: Inhibition of growth and reduction in tumorigenicity of UCI-107 ovarian cancer by antagonists of growth hormonereleasing hormone and vasoactive intestinal peptide. J Cancer Res Clin Oncol 127: 645-652, 2001.

18. Chatzistamou I, Schally AV, Varga JL, et al: Antagonists of growth hormone-releasing hormone and somatostatin analog RC-160 inhibit the growth of the OV-1063 human epithelial ovarian cancer cell line xenografted into nude mice. J Clin Endocrinol Metab 86: 2144-2152, 2001.

19. Plonowski A, Schally AV, Busto R, Krupa M, Varga JL and Halmos G: Expression of growth hormone-releasing hormone $(\mathrm{GHRH})$ and splice variants of GHRH receptors in human experimental prostate cancers. Peptides 23: 1127-1133, 2002.

20. Busto R, Schally AV, Varga JL, et al: The expression of growth hormone-releasing hormone (GHRH) and splice variants of its receptor in human gastroenteropancreatic carcinomas. Proc Natl Acad Sci USA 99: 11866-11871, 2002.

21. Garcia-Fernandez MO, Schally AV, Varga JL, Groot K and Busto R: The expression of growth hormone-releasing hormone (GHRH) and its receptor splice variants in human breast cancer lines; the evaluation of signaling mechanisms in the stimulation of cell proliferation. Breast Cancer Res Treat 77: 15-26, 2003

22. Pozsgai E, Schally AV, Zarandi M, Varga JL, Vidaurre I and Bellyei S: The effect of GHRH antagonists on human glioblastomas and their mechanism of action. Int J Cancer 127: 2313-2322, 2010

23. Heinrich E, Schally AV, Buchholz S, et al: Dose-dependent growth inhibition in vivo of $\mathrm{PC}-3$ prostate cancer with a reduction in tumoral growth factors after therapy with GHRH antagonist MZ-J-7-138. Prostate 68: 1763-1772, 2008.

24. Kovacs M, Schally AV, Hohla F, et al: A correlation of endocrine and anticancer effects of some antagonists of GHRH. Peptides 31: 1839-1846, 2010.

25. Bellyei S, Szigeti A, Boronkai A, et al: Inhibition of cell death by a novel $16.2 \mathrm{kD}$ heat shock protein predominantly via $\mathrm{Hsp} 90$ mediated lipid rafts stabilization and Akt activation pathway. Apoptosis 12: 97-112, 2007.

26. Rekasi Z, Czompoly T, Schally AV and Halmos G: Isolation and sequencing of cDNAs for splice variants of growth hormonereleasing hormone receptors from human cancers. Proc Natl Acad Sci USA 97: 10561-10566, 2000.

27. Pozsgai E, Schally AV, Halmos G, Rick F and Bellyei S: The inhibitory effect of a novel cytotoxic somatostatin analogue AN-162 on experimental glioblastoma. Horm Metab Res 42: 781-786, 2010.

28. Kahan Z, Arencibia JM, Csernus VJ, et al: Expression of growth hormone-releasing hormone (GHRH) messenger ribonucleic acid and the presence of biologically active GHRH in human breast, endometrial, and ovarian cancers. J Clin Endocrinol Metab 84: 582-589, 1999.

29. Chopin LK and Herington AC: A potential autocrine pathway for growth hormone releasing hormone $(\mathrm{GHRH})$ and its receptor in human prostate cancer cell lines. Prostate 49: 116-121, 2001.

30. Khorram O, Garthwaite M, Grosen E and Golos T: Human uterine and ovarian expression of growth hormone-releasing hormone messenger RNA in benign and malignant gynecologic conditions. Fertil Steril 75: 174-179, 2001.

31. Bagnato A, Moretti C, Ohnishi J, Frajese G and Catt KJ: Expression of the growth hormone-releasing hormone gene and its peptide product in the rat ovary. Endocrinology 130: 1097-1102, 1992.

32. Bellyei S, Schally AV, Zarandi M, Varga JL, Vidaurre I and Pozsgai E: GHRH antagonists reduce the invasive and metastatic potential of human cancer cell lines in vitro. Cancer Lett 293: 31-40, 2010.

33. Srivastava $\mathrm{CH}$, Monts BS, Rothrock JK, Peredo MJ and Pescovitz OH: Presence of a spermatogenic-specific promoter in the rat growth hormone-releasing hormone gene. Endocrinology 136: 1502-1508, 1995. 
34. Siriwardana G, Bradford A, Coy D and Zeitler P: Autocrine/ paracrine regulation of breast cancer cell proliferation by growth hormone releasing hormone via Ras, Raf, and mitogen-activated protein kinase. Mol Endocrinol 20: 2010-2019, 2006.

35. Kiaris H, Schally AV and Varga JL: Suppression of tumor growth by growth hormone-releasing hormone antagonist JV-1-36 does not involve the inhibition of autocrine production of insulin-like growth factor II in H-69 small cell lung carcinoma. Cancer Lett 161: 149-155, 2000.

36. Barabutis N and Schally AV: Knocking down gene expression for growth hormone-releasing hormone inhibits proliferation of human cancer cell lines. Br J Cancer 98: 1790-1796, 2008.

37. Zeitler P and Siriwardana G: Antagonism of endogenous growth hormone-releasing hormone (GHRH) leads to reduced proliferation and apoptosis in MDA231 breast cancer cells. Endocrine 18 $85-90,2002$.
38. Steinmetz R, Zeng P, King DW, Walvoord E and Pescovitz OH: Peptides derived from pro-growth hormone-releasing hormone activate p38 mitogen-activated protein kinase in GH3 pituitary cells. Endocrine 15: 119-127, 2001

39. Pombo CM, Zalvide J, Gaylinn BD and Dieguez C: Growth hormone-releasing hormone stimulates mitogen-activated protein kinase. Endocrinology 141: 2113-2119, 2000.

40. Volakaki AA, Lafkas D, Kassi E, Schally AV, Papavassiliou AG and Kiaris H: Essential role of p21/waf 1 in the mediation of the anti-proliferative effects of GHRH antagonist JMR-132. J Mol Endocrinol 41: 389-392, 2008

41. Hohla F, Buchholz S, Schally AV, et al: GHRH antagonist causes DNA damage leading to p21 mediated cell cycle arrest and apoptosis in human colon cancer cells. Cell Cycle 8: 3149-3156, 2009. 